\title{
The first record of the genus Pheidole Westwood, 1839 (Hymenoptera: Formicidae) from the Baltic amber
}

\author{
Первое указание рода Pheidole Westwood, 1839 (Hymenoptera: \\ Formicidae) из балтийского янтаря
}

\author{
D.A. Dubovikoff \\ A.A. Аубовиков \\ St.-Petersburg State University, 7/9 Universitetskaya nab., Saint-Petersburg 199034, Russia. E-mail: dubovikoff@gmail.com \\ Санкт-Петербургский государственный университет, Университетская наб., 7/9, Санкт-Петербург 199034, Россия.
}

KEY WORDS: ant, Pheidole, first record, new species, Baltic amber.

КЛЮЧЕВЫЕ СЛОВА: муравей, Pheidole, первое указание, новый вид, балтийский янтарь.

ABSTRACT. Occurrence of the genus Pheidole in the Baltic amber (late Eocene) is confirmed. The fourth fossil species of this genus, Pheidole rasnitsyni sp.n., is described.

РЕЗЮМЕ. Подтверждено нахождение рода Pheidole в балтийском янтаре (поздний эоцен). Описывается четвертый ископаемый вид этого рода - Pheidole rasnitsyni sp.n.

\section{Introduction}

The genus Pheidole Westwood, 1839 is the largest and the most widespread genus of ants. The number of described species of this genus exceeds 910 [Brown, 2000]. On the other hand, little is known about the fossil members of this genus because they are very rare in fossil resins and sediments. Among more than 17000 inclusions of ants from late Eocene European ambers studied to date [Dlussky, Rasnitsyn, 2009], representatives of the genus Pheidole are found for the first time. This paper is based on the material from the collection of Baltic amber which is now stored in the Zoological Institute of the Russian Academy of Sciences (St. Petersburg; ZISP). This material was mostly collected in Königsberg (now Kaliningrad) by Dr. Dampf (1912) and Dr. Noetlingk.

However, the first record of the genus Pheidole in Baltic amber (as well as fossil forms of this genus in general) belongs to G. Mayr [1868]. He has tentatively placed the species Formica cordata Holl, 1829 in the genus Pheidole [Holl, 1829]. In addition, pictures of this badly described species have been supposedly published earlier by A. Schweigger [1819]. Regretfully, the type of $F$. cordata was lost, and its original description seems not to adequately reflect taxonomic position of this species at the genus level.

Until now, fossil Pheidole species were reliably recorded from the Oligocene of the USA, Florissant [Carpenter, 1930] and from the Dominican amber [Bar- oni Urbani, 1995; Wilson, 1985]. The description of a new species of this genus from the Baltic amber is given below.

\section{Material and methods}

Two pieces of Baltic amber containing three workers of the new species were investigated. All types are deposited in the Zoological Institute of the Russian Academy of Sciences (St. Petersburg).

Morphometrics. The specimens were measured (up to $0.01 \mathrm{~mm}$ precision) using MC-2 ZOOM stereomicroscope.

Measurements: HL - maximum length of head in dorsal view, measured in a straight line from the most anterior point of clypeus to the most posterior point of occipital margin; HW - maximum width of head in dorsal view behind (above) the eyes; $\mathrm{ScL}$ - maximum straight-line length of scape from its articulation with condylar bulb to the proximal edge of scape; $\mathrm{AL}$ diagonal length of alitrunk seen in profile, from the anterodorsal point of alitrunk to the posterior margin of propodeal lobes; PL - maximum length of petiole from above, measured from the posterodorsal margin of petiole to its anterior edge at the articulation with propodeum; petiole should be positioned so that measured points lie on the same plane; PPL - maximum length of postpetiole from above; PPW — maximum width of postpetiole from above; OD - maximum diameter of eye. Cephalic index $-\mathrm{CI}=\mathrm{HW} / \mathrm{HL}$; scape index $-\mathrm{ScI}=\mathrm{ScL} / \mathrm{HL}$; postpetiole index PPI $=$ PPW/PPL.

\section{Taxonomic part}

Pheidole rasnitsyni sp.n.

Figs 1-5.

MATERIAL EXAMINED. Three workers in two pieces of amber. Holotype: worker no. DD 8/5; Late Eocene, Baltic amber; 

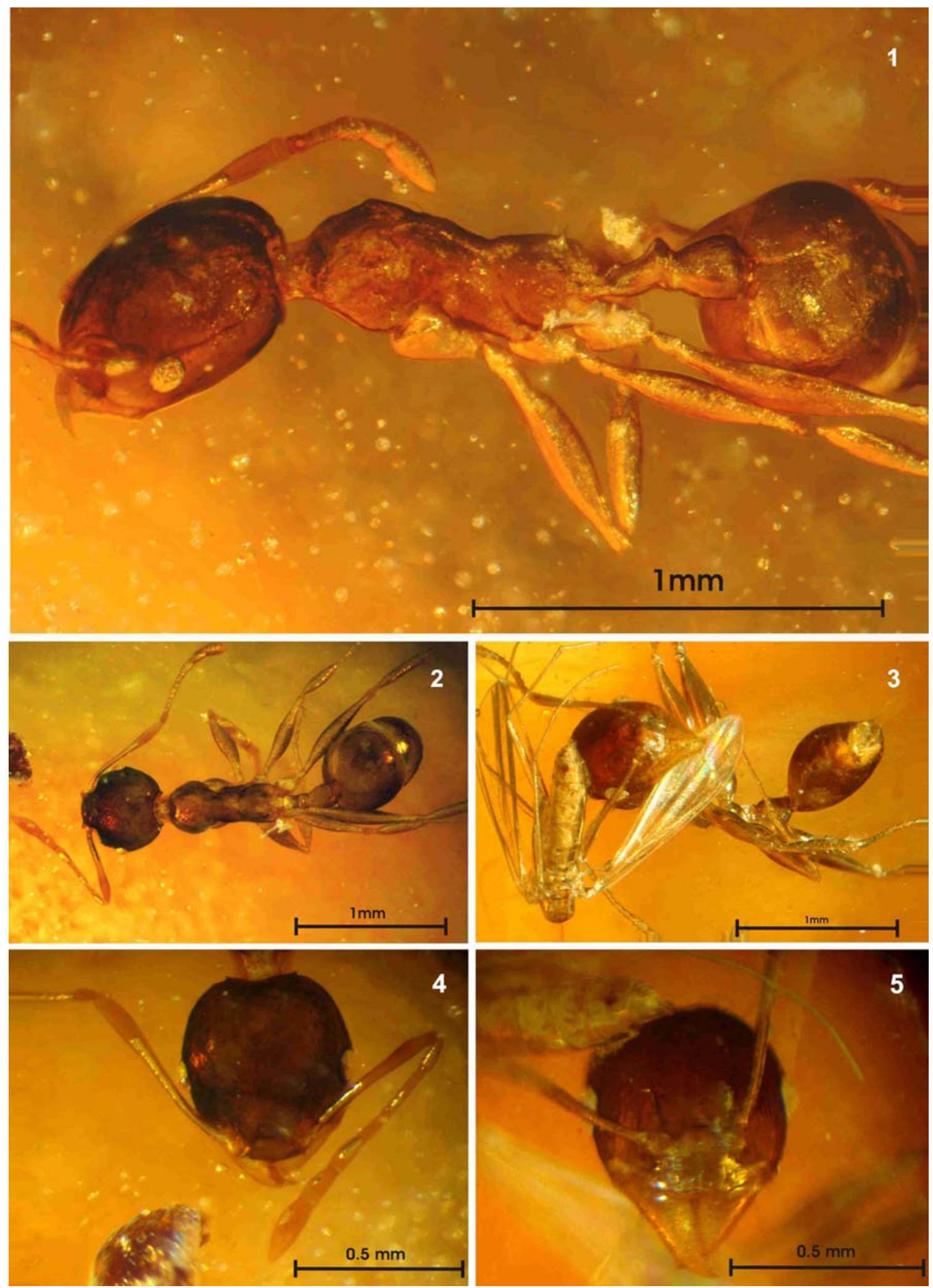

Figs 1-5. Pheidole rasnitsyni sp.n. (1, 2, 4 - holotype; 3, 5- paratype DD 9/6). 1 - habitus, lateral view; 2 - habitus, dorsal view; 3 - general view; 4 - head, dorsal view; 5 - mandibles, clypeal and frontal areas of head.

Pис. 1-5. Pheidole rasnitsyni sp.n. (1, 2, 4 - голотип; 3, 5 - паратип DD 9/6). 1 - габитус, вид сбоку; 2 — габитус, вид сверху; 3 - общий вид; 4 - голова, вид сверху; 5 - мандибулы, области клипеуса и лба головы. 
well-preserved inclusion. Paratypes. Poorly preserved worker (part of head, middle and hind legs); in the same piece of amber as holotype, together with bark beetle. Worker, no. DD 9/6; late Eocene, Baltic amber; well-preserved inclusion in the large piece of amber together with more than ten specimens of Apoidea.

DESCRIPTION. Holotype: $\mathrm{HW}=0.53, \mathrm{HL}=0.58$, $\mathrm{ScL}=0.63, \mathrm{AL}=0.69, \mathrm{PL}=0.19, \mathrm{PPL}=0.19, \mathrm{PPW}=$ $0.14, \mathrm{OD}=0.09, \mathrm{CI}=0.91, \mathrm{ScI}=1.09, \mathrm{PPI}=0.74$. Paratype (DD 9/6): $\mathrm{HW}=0.53, \mathrm{HL}=0.58, \mathrm{ScL}=0.69$, $\mathrm{CI}=0.91, \mathrm{ScI}=1.19$.

Total length (including mandibles) slightly exceeds $2.0 \mathrm{~mm}$. Body color uniform, yellowish-brown with somewhat paler appendages (Figs 1,2). Pronotum and mesonotum with several long setae (hardly seen in amber). Scape and flagellum, as well as femora and tibiae with numerous short erect or suberect hairs (Fig. 3 ). Surface of head and alitrunk with weakly expressed wrinkles and superficial micropunctation. Head slightly elongate, laterally broadly convex. Eyes moderately small and bulging (Figs 2-5). Scape quite long, stretching beyond occipital margin for more than five diameters of scape. Anterior clypeal margin broadly convex, slightly notched medially (Fig. 5). Frontal carinae straight, merged with wrinkles around antennal socket (Fig. 5). Mandibles with numerous small denticles and two apical moderately long teeth (Fig. 5).

Pronotum with small lateral tubercles. Pronotal declivity gradual, mesonotal groove weak. Propodeum with small and sharp triangular apical denticles, looking slightly apart (Fig. 1). Anterior face of petiole strongly concave; peduncle quite long; dorsum of petiolar node subtriangular, pointed at apex (in profile). Postpetiole broad, slightly cordate, almost as long as wide.

Females, males and soldiers unknown.

ETYMOLOGY. This species is named in honor of Professor A.P. Rasnitsyn, the famous Russian palaeoentomologist.

DISCUSSION. Pheidole rasnitsyni sp.n. is the fourth known and the most ancient species of the genus Pheidole. This species was described from two pieces of light amber, close to gedanit, a kind of Baltic amber, in their physical properties. In my opinion, this species is the most close to modern species of the genus Pheidole that are widespread in Southeast Asia. E.O. Wilson [1985] and C. Baroni Urbani [1995] have also made similar assumptions about the species from Dominican amber. Discussion regarding fossil and subfossil species (the latter forms are known from geologically young resins, i.e. copals, of Africa and Southeast Asia) of the genus Pheidole is given in the paper by Baroni Urbani [1995]. A list of all currently known fossil species of this genus (in geochronological order) is suggested below:

Pheidole rasnitsyni Dubovikoff, sp.n. - Late Eocene, Baltic amber.

Ph. tertiaria Carpenter, 1930 - Oligocene, Florissant shale.

Ph. tethepa Wilson, 1985 - Miocene, Dominican amber.

Ph. primigenia Baroni Urbani, 1995 - Miocene, Dominican amber.

Incertae sedis species: Pheidole cordata (Holl, 1829) — Late Eocene, Baltic amber (incertae sedis in Myrmicinae).

\section{ACKNOWLEDGMENTS}

I am very grateful to Prof. Gennady M. Dlussky (Moscow State University, Moscow, Russia) who gave me the first introduction to fossil ants several years ago and helped me to work on ants in amber. I am grateful to Dr. Wolfgang Weitschat (Geological-Paleontological Institute, University of Hamburg, Germany) for useful discussion on amber and properties of its different varieties. I also thank the Helicon Company for Helicon Focus software used to obtain full focus image of ants (www.heliconsoft.com). This work was supported by the grant of the President of the Russian Federation for leading scientific schools no. 3332.2010.4.

\section{References}

Baroni Urbani C. 1995. Invasion and extinction in the West Indian ant fauna revisited: the example of Pheidole. (Amber Collection Stuttgart: Hymenoptera, Formicidae. VIII: Myrmicinae, partim) // Stuttgarter Beiträge zur Naturkunde Serie B (Geologie und Paläontologie). No.222. P.1-29.

Brown W.L., Jr. 2000. Diversity of ants // Agosti D., Majer J.D., Alonso L.E., Schultz T.R. (eds.). Ants: standard methods for measuring and monitoring biodiversity. Washington, London: Smithsonian Institution Press. P.45-79.

Carpenter F.M. 1930. The fossil ants of North America // Bulletin of the Museum of Comparative Zoology at Harvard College. No.70. P.1-66.

Dlussky G.M., Rasnitsyn A.P. 2009. [Ants in the Upper Eocene amber of central and eastern Europe] // Paleontological Journal. Vol.43. No.9. P.1024-1042 [in Russian].

Holl F. 1829. Handbuch der Petrefactenkunde. Bd.2. S.117-232.

Mayr G. 1868. Die Ameisen des baltischen Bernsteins // Beiträge zur Naturkunde Preussens. Königlichen Physikalisch-Ökonomischen Gesellschaft zu Königsberg. Vol.1. P.1-102.

Schweigger A.F. 1819. Beobachtungen auf naturhistorischen Reisen. Anatomisch-physiologische Untersuchungen über Corallen; nebst einem Anhang, Bemerkungen über den Bernstein enthaltend. Berlin. $127 \mathrm{~S}$.

Wilson E.O. 1985. Ants of the Dominican amber. 1. Two new myrmicine genera and an aberrant Pheidole // Psyche. Vol.92. No.1. P.1-9. 